UDC 616-008,6; 612.2

DOI: $10.21668 /$ health.risk/2020.2.17.eng

\title{
DEVELOPING NEW APPROACHES TO HYPERLIPIDEMIA CORRECTION TAKING INTO ACCOUNT CHANGES IN FATTY ACIDS STRUCTURE OF BLOOD SERUM
}

\author{
D.M. Azizova ${ }^{1}$, I.R. Mavlyanov ${ }^{2}$, R.A. Sabirova ${ }^{1}$, M.U. Kulmanova ${ }^{1}$, \\ A.B. Soliev ${ }^{2}$, G.Zh. Zharylkasynova ${ }^{3}$
}

${ }^{1}$ Tashkent Medical Academy, 2 Farobi Str., Tashkent, 100109, Uzbekistan

${ }^{2}$ Republican Scientific and Practical Center for Sport Medicine at the National Olympic Committee of Uzbekistan, 6 Almazar Str., Tashkent, 100027, Uzbekistan

${ }^{3}$ Bukhara State Medical Institute named after Abu Ali ibn Sino, 1 Navoi Ave., Bukhara, 200118, Uzbekistan

It is still a pressing issue in contemporary medicine to examine pathogenesis mechanisms and update procedures aimed at treating atherosclerosis. Developments by domestic and foreign researchers revealed that complex molecular and cellular studies on a mechanism of impacts exerted by vegetative-based medications, produced both domestically and abroad and used to treat atherosclerosis, were of primary importance in practical medicine in terms of educing population health risks. It is assumed that disorders in formation and transfer of non-esterified fatty acids (NEFA) in blood plasma are a major reason for hypertriglyceridemia occurrence.

The article contains research data on lipid metabolism parameters taken in dynamics of experimental hypercholesterolemia development. Performed research allowed revealing hypolipidemic effects produced by a biologically active additive called Biomays. We developed theoretical grounds for recommendations that should be given to patients suffering from hyperlipidemia and not getting proper therapeutic effects form treatment with statins. We recommend a complex approach which includes a BAA (biologically active additive) Biomays made of dried wheat sprouts in order to reduce risks caused by complications related to treatment with statins.

Our research goal was to develop new approaches to correcting hyperlipidemia basing on changes in fatty acids structure of blood serum.

The experiments were performed on 30 male rabbits belonging to chinchilla breed with initial body mass equal to 2,500-3,00 grams; animals were divided into 5 groups, 6 animals in each, depending on a research goal and treatment procedures. We started a 30-day treatment of experimental animals with ultrox and Biomays in doses equal to $0.6 \mathrm{mg} / \mathrm{kg}$ and $142 \mathrm{mg} / \mathrm{kg}$ accordingly after they had been given cholesterol for 2 months. We determined fatty acids structure of blood serum with a triple quadrupole chromato-mass-spectrometer with gas chromatographer (GC-MS/MS) TRACE 1310 TSQ 8000 and automated autosampler CTC TriPlus RSH produced by Thermo Fisher Scientific (the USA).Combined application of ultrox and Biomays led to more significant hypolipidemic effects. Use of statins and wheat sprouts had a distinct positive effect on contents of saturated and poly-unsaturated fatty acids $n$ blood such as linoleic acid and linolenic acid.

Key words: fatty acids, water-soluble vitamins, policosanol, Biomays biologically active additive, mass-spectrometry, gas chromatography, hyperlipidemia.

Cardiovascular diseases, especially ischemic heart disease (IHD), remain the most widely spread ones all over the world; more than $50 \%$ mortality cases occur due to these pathology. A considerable increase in cardio- vascular morbidity and mortality among young people and employable population is especially alarming [1-3]. These pathologies are caused by numerous risk factors; it makes them even graver and undoubtedly requires

(C) Azizova D.M., Mavlyanov I.R., Sabirova R.A., Kulmanova M.U., Soliev A.B., Zharylkasynova G.Zh., 2020

Dilzoda M. Azizova - Doctor of Philosophy, Senior lecturer at the Medical and Biological Chemistry Department (e-mail: dilzoda89@yandex.ru; tel.: +9 (98901) 78-12-21; ORCID: https://orcid.org/0000-0002-4824-0834).

Iskandar R. Mavlyanov - Doctor of Medical Sciences, Professor, Head of the Clinical Pharmacology Department (e-mail: iskandar.mavlyanov@inbox.ru; tel.: +9 (98946) 08-78-95; ORCID: https://orcid.org/0000-0001-5470-3498).

Rikhsi A. Sabirova - Doctor of Medical Sciences, Professor at the Medical and Biological Chemistry Department (e-mail: sabirovara@yandex.ru; tel.: +9 (98901) 87-53-84; ORCID: https://orcid.org/0000-0001-6119-5225).

Munozhat U. Kulmanova - Doctor of Medical Sciences, Head of the Medical and Biological Chemistry Department (e-mail: Munojat.kulmanova@mail.ru; ORCID: https://orcid.org/0000-0001-9131-7393).

A"zamzhon B. Soliev - Doctor of Medical Sciences, Head of the Research Laboratory (e-mail: 1136001@gmail.com; tel.: +9 (98712) 41-52-49, ORCID:https://orcid.org/0000-0002-3596-6628).5.

Gaukhar Zh. Zharylkasynova - Candidate of Medical Sciences, Associate Professor at the Department for Skills Development for general practitioners at the Skills Development Faculty, Deputy Rector responsible for education (e-mail: gavhar72@inbox.ru; tel.: +9 (98914) 48-48-26; ORCID: https://orcid.org/0000-0001-5376-3034). 
correction. Therefore, activities aimed at preventing cardiovascular diseases have national significance [4-6]. Today, it is still vital to develop highly efficient prevention techniques, pre-clinic diagnostics, and therapy aimed at treating atherosclerosis; this scientific and medical-social task is hard to solve [7,8]. At present it is obvious that hypercholesterolemia has become a global non-communicable epidemic. As per data provided by the Uzbekistan Public Healthcare Ministry, in 2014 circulatory system diseases amounted to approximately 5,800 cases per 100 thousand people and tended to grow. Ischemic heart disease (IHD) was the most frequent cause of death accounting for 22,300 deaths per year [9-11].

Hypercholesterolemia (HCS) plays an important role in atherosclerosis and IHD pathogenesis [12-14]. Prescribing medications that reduce cholesterol is a priority in IHD and HCS treatment. Inhibitors of 3-hydroxy-3methyl-glutaril-CoA reductase are the most efficient in reducing low density lipoprotein cholesterol (CS-LDLP) and mortality caused by atherosclerosis and IHD [15-17]. Effective therapeutic daily dose of many statins causes side effects such as an increase in liver enzymes concentrations, aspartate and alanine transaminase (ALT and AST), myalgia, and myopathy with an increase in creatinine phosphokinase (CPK) concentration.

Every year there is a growth in number of research works focusing on searching for alternative hypolipidemic remedies. Leading role among them belongs to natural preparations. Over the last years, researchers have shown certain interest in wheat germ and wheat germ flour. Some data obtained by foreign researchers on effects produced by wheat germ oil and wheat germ flour on cholesterol contents in blood and liver have become a precondition for testing them in treating various cardiovascular diseases. As we can see from the data given in Figure 1, cholesterol contents in rats' blood and liver apparently goes down significantly due to use of wheat germ oil against use of cotton or soya oil [14, 15, 18-21].

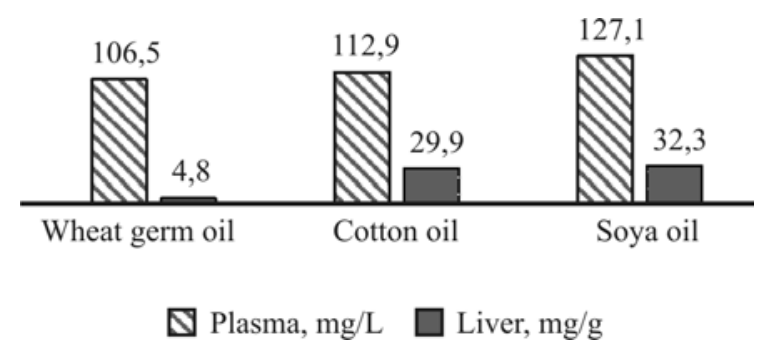

Figure 1. Effects produced by wheat germ oil on cholesterol contents in rats' blood and liver ${ }^{1}$

Other researchers revealed that a diet with $7 \%$ wheat germ resulted in 5-10\% decrease in cholesterol contents in blood against the reference group. Besides, wheat germ flour consumption didn't cause any side effects or allergic reactions. Researchers at the Therapy and Neurology Department of the Kharkov Medical Academy for Postgraduate Studies examined effects produced by wheat germ oil on patients with ischemic heart disease (angina pectoris, II and III functional category). Analysis of changes in blood biochemical structure revealed that when wheat germ oil was applied for treating patients with ischemic heart disease, it resulted in a more valid hypolipidemic effect (a decrease in lipids and $\beta$-lipoproteins contents). Positive results were also yielded as regards clinical course of the disease. Thus, when clinical picture was assessed in those patients who were additionally given wheat germ oil, it was revealed that a number of angina pectoris attacks went down by 4 times (by 2.5 times only in the reference group), and, accordingly, nitroglycerine doses also decreased. And patients from the test group endured physical loads better than their counterparts from the reference one. It was also noted that use of wheat germ oil in treatment was accompanied with a decrease in elevated coagulability that was very important from pathogenetic point of view [18-20].

Similar research performed by N.S. Radionova and O.A. Sokolova also showed that there was positive dynamics in blood lipid spectrum when a patient took wheat germ oil; it was confirmed by lower contents of choles-

\footnotetext{
${ }^{1}$ L.A. Shpagina. Use of wheat germ oil and Vitasar in treating internal diseases: methodical guidelines for doctors. Novosibirsk, Novosibirsk printing house Publ., 2008, 80 p. (in Russian).
} 
terol and cholesterol in low density lipoproteins, and, more importantly, by higher contents of anti-atherogenic high density cholesterol [21, 22].

In Novosibirsk Medical Academy L.A. Shpagina supervised assessment of wheat germ oil efficiency in treating workers with cardiovascular diseases [23, 24]. The results revealed that patients who were prescribed a combined hypolipidemic diet and wheat germ oil had authentic improvement in their health, weaker clinical symptoms, and positive dynamics in blood lipids spectrum. Hypolipidemic effects were persistent and remained even 3 months after the therapy was over. Consequently, this analysis of research works that focused on examining effects produced by wheat germ oil and flour on levels and spectra of blood lipids in case of hyperlipidemia shows that these products exert apparent and persistent hypolipidemic impacts and it is a precondition for conducting further targeted studies in the sphere.

Our research goal was to develop new approaches to correcting hyperlipidemia basing on changes in fatty acid structure of blood serum.

Data and methods. Given all the above stated, we conducted an experimental study on effects produced by Biomays food additive on blood lipids spectrum and fatty acids structure in animals with modeled experimental hypercholesterolemia.

Our experiments were performed on 30 male «Chinchilla» rabbits with initial body mass being 2,500-3,000 grams; the animals were divided into 5 groups, 6 animals in each, depending on research goals and a chosen therapy. Experimental animals started to receive their treatment after 2-month cholesterol intake [25]. To comparatively assess effects produced on blood serum by Biomays vegetable preparation and ultrox statin, we determined contends of triglycerides (TG), total cholesterol (TCS), high density lipoproteins cholesterol (CS HDLP), low density lipoproteins (LDLP), very low density lipoproteins (VLDLP) with an automated biochemical analyzer (RX Daytona/Randox, Great Britain) and calculated atherogenicity coefficient (AC).
A procedure for determining fatty acids structure in blood plasma. Fatty acids structure in blood serum was determined at the scientific laboratory of the Republican Scientific and Practical Center for Sport Medicine at the Uzbekistan national Olympic Committee; to do that, we applied TRACE 1310 TSQ 8000, a triple quadrupole chromate-mass-spectrometer with a gas chromatographer (GC-MS/MS) and autosampler CTC TriPlus RSH produced by Thermo Fisher Scientific (the USA).

Blood serum was first separated from red corpuscles via whole blood centrifuging at 2,000 turns per minute for 6 minutes. Then $0.5 \mathrm{ml}$ of supernatant (blood serum) were put into $1.5-\mathrm{ml}$ calibrated eppendorf vials and added with $0.4 \mathrm{ml}$ acetone in order to sediment protein fraction in them. The mixture was thoroughly mixed in a vortex for $0.5-1$ minute and then centrifuged at 15,000 turns per minute for 10 minutes. After that supernatants with their volume being $0.3-0.4 \mathrm{ml}$ were put into new eppendorf vials and added with $0.25 \mathrm{ml}$ hexane for fatty acids extraction. The mixture was again thoroughly mixed in a vortex and left for several minutes in order to achieve complete separation between water and hexane layers. Hexane layer was put into new eppendorf vials and extraction was repeated two more times in order to completely extract chemicals with lipid essence. Obtained hexane layers were evaporated in a microconcentrator until dry and then obtained sediments were dissolved in $0.5 \mathrm{ml}$ hexane and put into glass vials for further GC-MS/MS analysis.

Chromatography conditions were as follows: there was a capillary column $(0.2 \mu \mathrm{M}$. $0.25 \mathrm{~mm} \cdot 30 \mathrm{~m}$ ) impregnated with $5 \%$ biphenyl-dimethylsiloxane; helium was chosen as a carrier gas with constant flow equal to $1 \mathrm{ml} / \mathrm{min}$. Initial temperature of the column thermostat was $40^{\circ} \mathrm{C}$ with 1-minute delay. Then thermostat was heated to $280{ }^{\circ} \mathrm{C}$ at a rate $20^{\circ} \mathrm{C} / \mathrm{min}$ with a 3 -minute delay at $280^{\circ} \mathrm{C}$ and a consequent temperature fall to its initial state during 6 minutes at a rate $40{ }^{\circ} \mathrm{C}$ per minute. Injector and mass spectrometer detector temperatures were set at $250{ }^{\circ} \mathrm{C}$. Extract was input in a volume equal to $1 \mu \mathrm{l}$ in a split flow mode. 
Ionization was performed with an electron impact at $20 \mathrm{eV}$. A chromatographic profile was registered 3 minutes after the start in order to remove a signal belonging to a solvent. Chromatography was controlled with XCalibur program within values limits range being $\mathrm{m} / \mathrm{z}$ 50-1,500. Components were identified with etalon lass-spectra taken from «NIST» library for etalon mass-spectra of natural substances.

All the obtained data were statistically processed with applied computer software for statistical analysis.

Results and discussion. Table 1 contains all the obtained data. A cholesterol diet the experiment animals were put on for 60 days resulted in apparent hypercholesterolemia
$(295.0 \pm 1.45 \mathrm{mg} / \mathrm{dL})$. Treatment with ultrox and Biomays food additive led to a decrease in cholesterol contents, by 2.08 and 1.49 times accordingly $(p<0.05)$. When ultrox and Biomays were taken together, it resulted in a more apparent decrease in TCS contents.

It should be noted that a decrease in TCS contents in animals that were given ultrox and Biomays were quite comparable. There was an authentic difference in TCS levels between animals from all the experimental groups and from the reference one 30 days after combined intake of two preparations, by $7.75-26.8 \%$ $(p<0.05)$; it indicates that combined intake of ultrox and Biomays is efficient in terms of cholesterol contents reduction.

Table 1

Lipid metabolism parameters in rabbits with experimental HCS, $n=6$

\begin{tabular}{|c|c|c|c|c|c|}
\hline \multirow[b]{2}{*}{ Parameter } & \multirow{2}{*}{$\begin{array}{l}\text { Reference } \\
\text { group }\end{array}$} & \multirow{2}{*}{$\begin{array}{c}\text { Animals with } \\
\text { experimental } \\
\text { HCS }\end{array}$} & \multicolumn{3}{|c|}{ After treatment } \\
\hline & & & Ultrox & Byomais & $\begin{array}{l}\text { Both prepara- } \\
\text { tions combined }\end{array}$ \\
\hline $\mathrm{TCS}, \mathrm{mg} / \mathrm{dL}$ & $71.8 \pm 0.78$ & $295 \pm 1.45$ & $142 \pm 0.66$ & $179 \pm 1.77$ & $131 \pm 1.2$ \\
\hline $\mathrm{TG}, \mathrm{mg} / \mathrm{dL}$ & $14.6 \pm 0.6$ & $28.1 \pm 0.36$ & $29.4 \pm 0.66^{*}$ & $37.3 \pm 0.54$ & $25.6 \pm 0.12$ \\
\hline CS HDLP, mg/dL & $26.7 \pm 0.98$ & $17.8 \pm 0.8$ & $29.6 \pm 0.7$ & $25.3 \pm 1.08$ & $34.8 \pm 0.75$ \\
\hline CS VLDLP mg/dL & $2.92 \pm 0.07$ & $6.98 \pm 0.15$ & $5.9 \pm 0.22$ & $7.46 \pm 0.21^{*}$ & $5.12 \pm 0.68$ \\
\hline CS LDLP mg/dL & $40.78 \pm 0.86$ & $270.3 \pm 2.8$ & $106.7 \pm 0.68$ & $146 \pm 1.88$ & $91.08 \pm 0.14$ \\
\hline $\mathrm{AC}$ & $1.37 \pm 0.02$ & $15.6 \pm 0.43$ & $3.83 \pm 0.14$ & $6.16 \pm 0.12$ & $2.76 \pm 0.44$ \\
\hline
\end{tabular}

$\mathrm{N}$ o t e: * means $p<0.05$ against the animals that were not given any treatment.

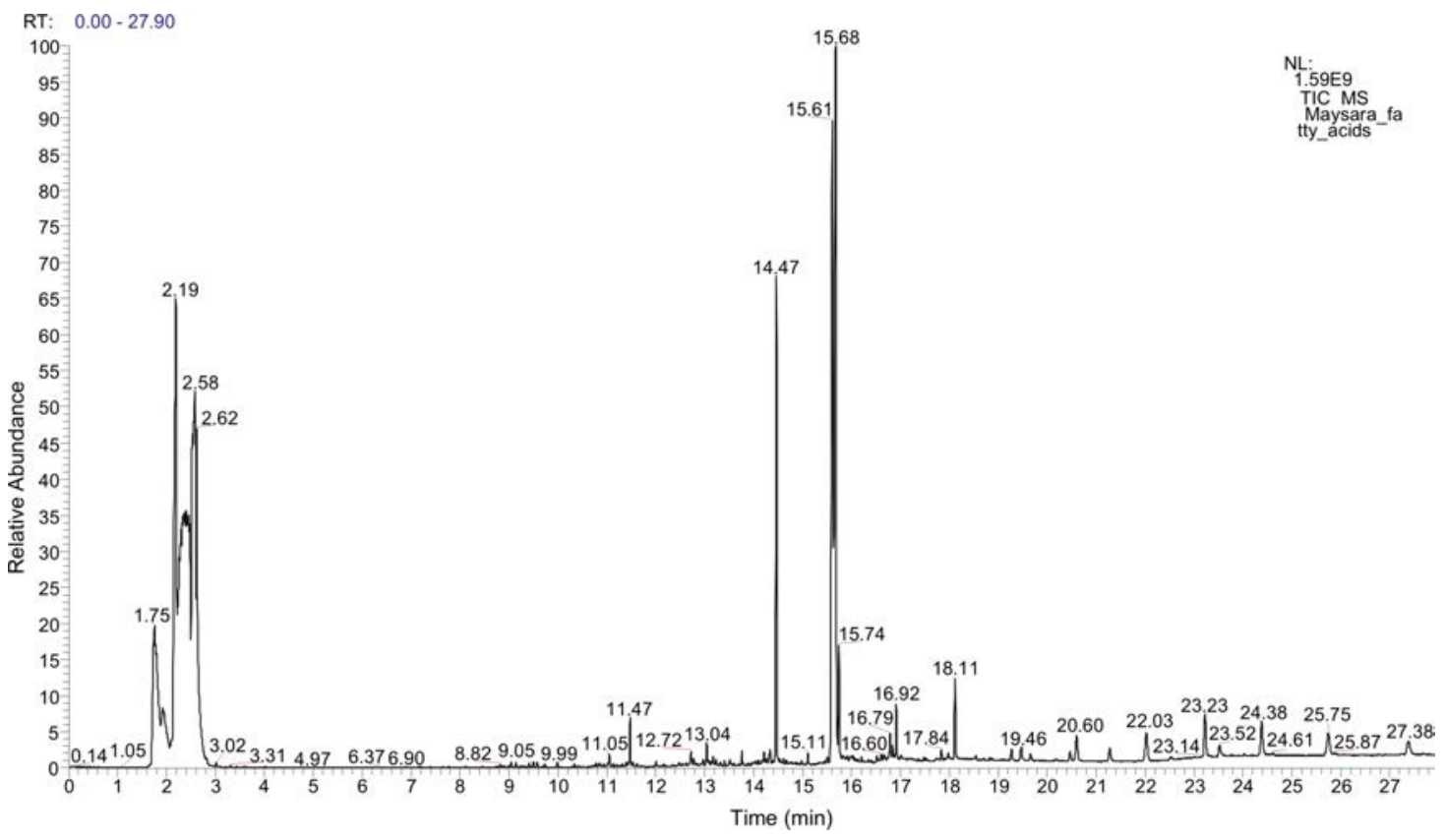


If we look at other blood lipids parameters in animals with $\mathrm{HCS}$, in particular, TG contents, we can see that it was 1.92 times higher than in the reference group $(p<0.05)$. There were no authentic changes in TG contents after treatment with ultrox ${ }^{2}$ [26-31].

Therefore, it seems vital to create a polycomponent biologically active substance with hypolipidemic properties; it can potentially be useful not only for treating mild lipid metabolism disorders but also for combined therapy when it is taken with statins in order to decrease their doses and, consequently, reduce their side effects.

To examine impacts exerted by Biomays on fatty acids contents in blood serum, we first of all examined fatty acids structure of Biomays food additive itself. The results are given in Figure 2.

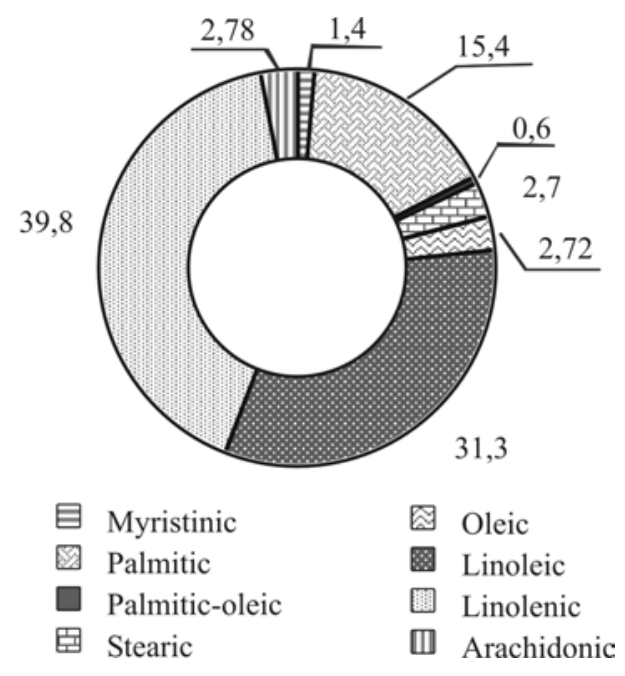

Figure 2. Biomays fatty acid structure in $\%$ per $1 \mathrm{mg}$

Saturated fatty acids in Biomays are mostly palmitic and stearic acids. At the same time, the greatest specific weight in fatty acids structure belongs to linoleic $(31.3 \%)$ and linolenic acids (39.8\%). Consequently, a substantial amount of fatty acids, including unsaturated ones, are linoleic and linolenic acids that have great physiological significance for a body [32-36].
Linoleic acid is well known to be the basic one as regards physiological effects; the acid is transformed into arachidonic acid in a body and the latter is an important component in lipid metabolism. The process occurs with vitamins $A$ and $E$ participating in it [37-39].

Besides, linoleic acid belongs to Omega- 6 family, while linoleic acid - to Omega-3, although both families, Omega- 6 and Omega-3 consist of 11 poly-unsaturated fatty acids (Table 2 and 3 ).

Fatty acids within Biomays structure (analysis):

$-9.73 \mathrm{~min}$; methyl ether of decanoic acid;

$-11.05 \mathrm{~min}$; eicosan;

- $13.04 \mathrm{~min}$; tetra-decanoic acid;

- $13.76 \mathrm{~min}$; penta-decanoic acid;

- 14.34 min; 9-hexane acid;

- 14.47 min; palmitic acid;

- $15.61 \mathrm{~min}$; linoleic acid;

$-15.68 \mathrm{~min}$; linolenic acid ( $\alpha$-form)

(Omega-3);

- 15.74 min; stearic acid;

- $16.52 \mathrm{~min}$; 9-cys, 11-trans, 13-transcoctadecatrienoic acid;

- $16.79 \mathrm{~min} ;$ 10.13-eicosadienic acid;

- $16.84 \mathrm{~min} ; 6,9,12,15$-docosatetraenoic acid;

- 16.92 min; eicosan acid.

Our study on fatty acid structure of Biomays food additive revealed that some other poly-unsaturated fatty acids from Omega-3 and Omega- 6 families could be found there, for example docosatetraenic (arachidonic) acid (Omega-6), eicosapentadienic acid (Omega-3), and octadecatrienic acid (Omega-6). But still, it should be noted that the greatest specific weights among them belong to linoleic and linolenic acids. These polyunsaturated fatty acids as components in Biomays food additive have certain physiological significance for a body. Indeed, polyunsaturated fatty acids produce positive effects, first of all, on fat metabolism as they accelerate lipid oxidation intensity [40, 41]. Besides, they participate in detoxification of a body, support immunity

\footnotetext{
${ }^{2}$ Diagnostics and correction of lipid metabolism disorders aimed at preventing and treating atherosclerosis: national recommendations. In: V.V. Kukharchuk, G.A. Konovalov [et al.] eds. Moscow, 2009, 50 p. (in Russian).
} 
Structure of Omega-6 family containing poly-unsaturated fatty acids

\begin{tabular}{|c|l|l|}
\hline$№$ & Poly-unsaturated fatty acids & \multicolumn{1}{|c|}{ Chemical structure } \\
\hline 1 & Linoleic acid & $18: 2 \omega 6$, cys,cys-9,12-octadecadienoic acid \\
\hline 2 & $\gamma$-linolenic acid & $18: 3 \omega 6$, cys, cys, cys-6,9,12-octadecatrienoic acid \\
\hline 3 & Calendic acid & $18: 3 \omega 6,8$-trans,10-trans,12-cys- octadecatrienoic acid \\
\hline 4 & Eicosadienic acid & $20: 2 \omega 6$, cys,cys-11,14-eicosadienic acid \\
\hline 5 & Dihomo- $\gamma$-linolenic кислота & $20: 3 \omega 6$, cys,cys,cys- $8,11,14-$-eicosatrienic acid \\
\hline 6 & Arachidonic acid & $20: 4 \omega 6$, cys,cys,cys,cys-6,9,12,15- eicosatrienic acid \\
\hline 7 & Docosadienic acid & $22: 2 \omega 6$, cys,cys-13,16-docosadienic acid \\
\hline 8 & Adrenic acid & $22: 4 \omega 6$, cys,cys,cys,cys-7,10,13,16- docosadienic acid \\
\hline 9 & Docosapentaenic acid & $22: 5 \omega 6$, cys,cys,cys,cys,cys-4,7,10,13,16-docosapentaenic acid \\
\hline 10 & Tetracosatetraenic acid & $24: 5 \omega 6$, cys,cys,cys,cys,cys-6,9,12,15,18-tetracosapentaenic acid \\
\hline 11 & Tetracosapentaenic acid & $24: 5 \omega 6$, cys,cys,cys,cys,cys-6,9,12,15,18- tetracosapentaenic acid \\
\hline
\end{tabular}

Structure of Omega-3 family containing poly-unsaturated fatty acids

\begin{tabular}{|c|l|l|}
\hline № & Poly-unsaturated fatty acids & \multicolumn{1}{c|}{ Chemical structure } \\
\hline 1 & Hexadecatrienic acid & $16: 3 \omega 3$, cys,cys,cys-7,10,13-hexadecatrienic acid \\
\hline 2 & -linoleic acid & $18: 3 \omega 3$, cys,cys,cys-9,12,15-octadecatrienic acid \\
\hline 3 & Stearic (stioridic) acid & $18: 4 \omega 3$, cys,cys,cys,cys-6,9,12,15-octadecatetraenic acid \\
\hline 4 & Eicosatrienic acid & $20: 3 \omega 3$, cys,cys,cys-11,14,17-eicosatrienic acid \\
\hline 5 & Eicosatetraenic acid & $20: 4 \omega 3$, cys,cys,cys-8,11,14,17-eicosatetraenic acid \\
\hline 6 & Eicosapentaenic acid & $20: 5 \omega 3$, cys,cys,cys,cys,cys-5,8,11,14,17-eicosapentaenic acid \\
\hline 7 & Geneicosapentaenic acid & $21: 5 \omega 3$, cys,cys,cys,cys,cys-6,9,12,15,18- geneicosapentaenic acid \\
\hline 8 & Docosapentaenic acid & $\begin{array}{l}22: 5 \omega 3, \text { clupanodonic acid, cys,cys,cys,cys,cys-7,10,13,16,19-docosa- } \\
\text { pentaenic acid }\end{array}$ \\
\hline 9 & Docosahexaenic acid & $22: 6 \omega 3$, cys,cys,cys,cys,cys,cys-4,7,10,13,16,19- docosahexaenic acid \\
\hline 10 & Tetracosapentaenic acid & $24: 5 \omega 3$, cys,cys,cys,cys,cys-9,12,15,18,21- docosahexaenic acid \\
\hline 11. & Tetracosahexaenic acid & $24: 6 \omega 3$, cys,cys,cys,cys,cys,cys-6,9,12,15,18,21- tetracosahexaenic acid \\
\hline
\end{tabular}

and hormonal balance in it thus exerting favorable influence on functions performed by many organs and systems, for example, the digestive, cardiovascular, endocrine, and nervous systems etc. Moreover, polyunsaturated fatty acids become involved into energy formation and turn out to be basic energy suppliers for a body just as any other fatty acids. The promote decrease in total cholesterol contents in blood, increase in high density lipoproteins contents, and decrease in low density lipoproteins contents [42-44]. It is probably due to this mechanism that positive shifts in lipid blood spectrum were revealed in our research. Together with hypolipidemic effects Omega-3 fatty acids also produce positive effects on co- agulation via reducing thrombocytes aggregation as well as increase oxygen inflow to tissue and reduce arterial hypertension [45].

Omega- 6 polyunsaturated fatty acids, just as Omega-3 ones, have a lot of benign physiological properties. Their derivatives accelerate regeneration in tissues, participate in immune system regulation and, above all, reduce cholesterol contents in blood that makes for a reduced risk of atherosclerosis. It is probably these effects that predetermined positive dynamics in blood lipids spectrum that we obtained for animals with experimental hypercholesterolemia.

Biomays food additive, apart from comparatively large amounts of polyunsaturated 


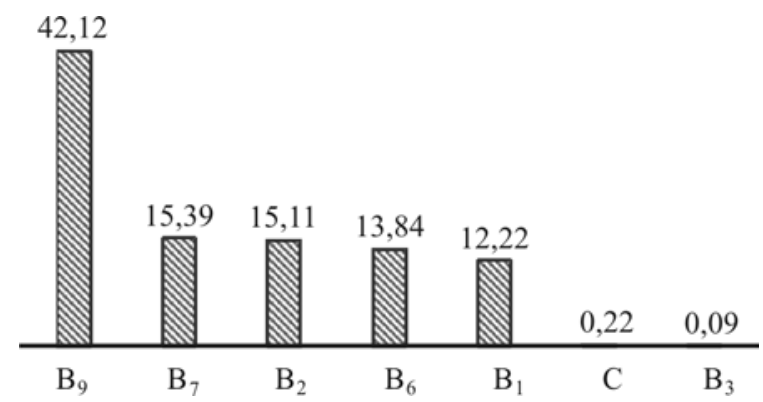

Figure 3. Structure and contents (in \%) of water-soluble vitamins in Biomays food additive

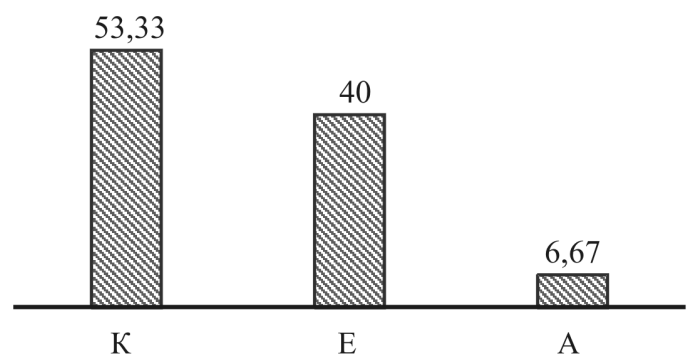

Figure 4. Structure and contents (in \%) of fat-soluble vitamins in Biomays food additive

fatty acids, also contains many water-soluble and fat-soluble vitamins. Their contents and structure are given in Figures 3 and 4. As we can see, Biomays food additive contains quite a significant number of different vitamins. The greatest share among water-soluble vitamins belongs to $\mathrm{B}_{9}$ or folic acid, namely $2 / 5$ of all the water-soluble vitamins. At the same time, other vitamins from group B have almost identical shares. Thus, specific weight of biotin (B7) amounts to $15.39 \%$, specific weight of $\mathrm{B}_{2}, 15.11 \% ; \mathrm{B}_{6}$ and $\mathrm{B}_{1}, 13.84 \%$ and $12.22 \%$ accordingly. So, water-soluble vitamins structure is quite diverse in this food additive and it is good for physiological processes in a body. At the same time, fat-soluble vitamins are mostly $\mathrm{K}, \mathrm{E}$ and $\mathrm{A}$, and $90 \%$ belong to vitamins $\mathrm{K}$ and $\mathrm{E}$ (Figure 4). Rather high specific weight of vitamin $\mathrm{E}$ is necessary for transforming linoleic acid into arachidonic one. Still, vitamin structure of the examined food additive indicates it is quite good for a body.

Vitamin $\mathrm{B}_{9}$ or folic acid has the biggest share among water-soluble vitamins and takes active part in synthesis of many biologically active substances that are important for vital activities performed by cells and tissues [46].

Results of our research revealed effects produced by Biomays food additive on fatty acids structure of blood taken from animals with hypercholesterolemia. The chromatograms show that treatment with this product results in considerable shifts in fatty acid spectrum in experimental animals against the initial one (Figure 5). It becomes especially apparent by the end of the $2^{\text {nd }}$ month after treatment started (Figure 2).

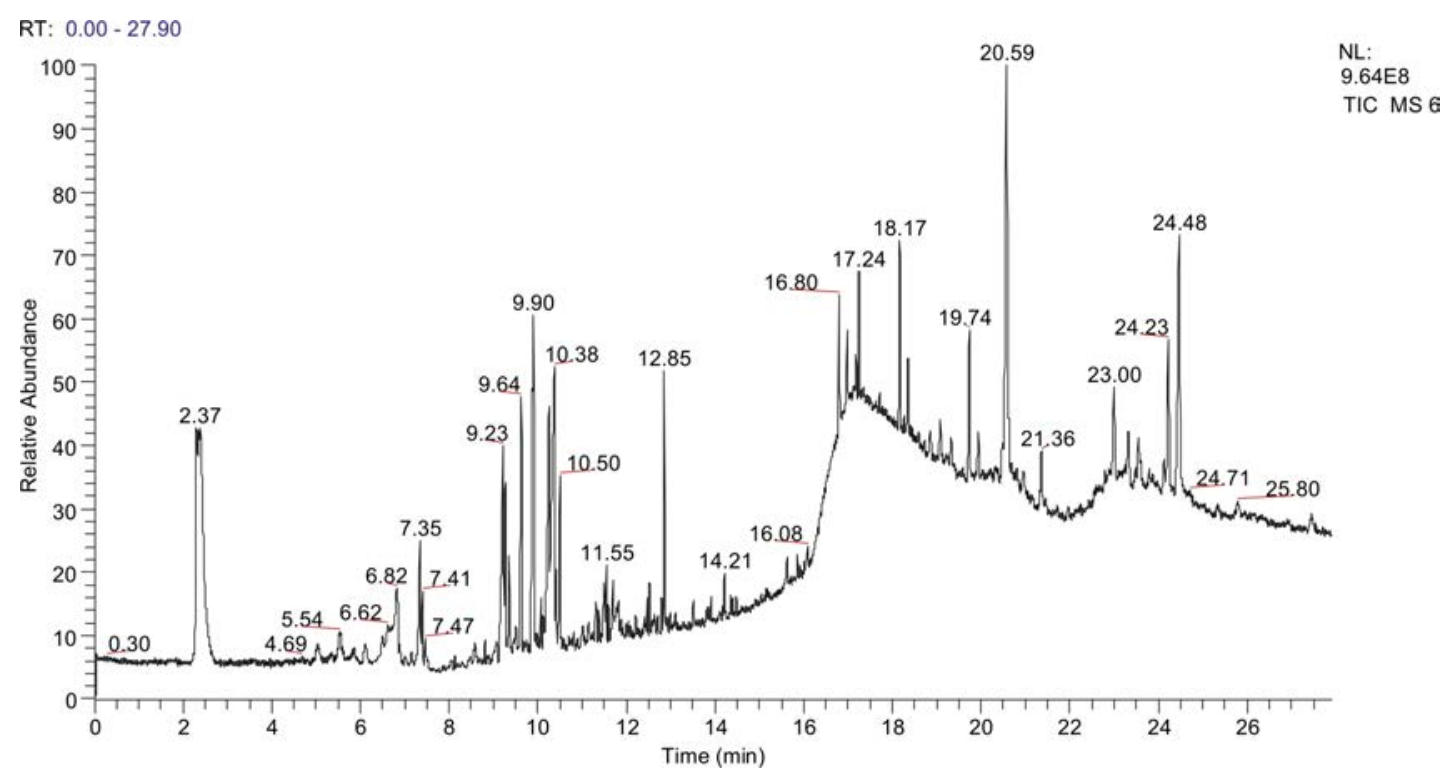

Figure 5. Fatty acids structure of blood taken from experimental animals with hypercholesterolemia prior to preparations intake 


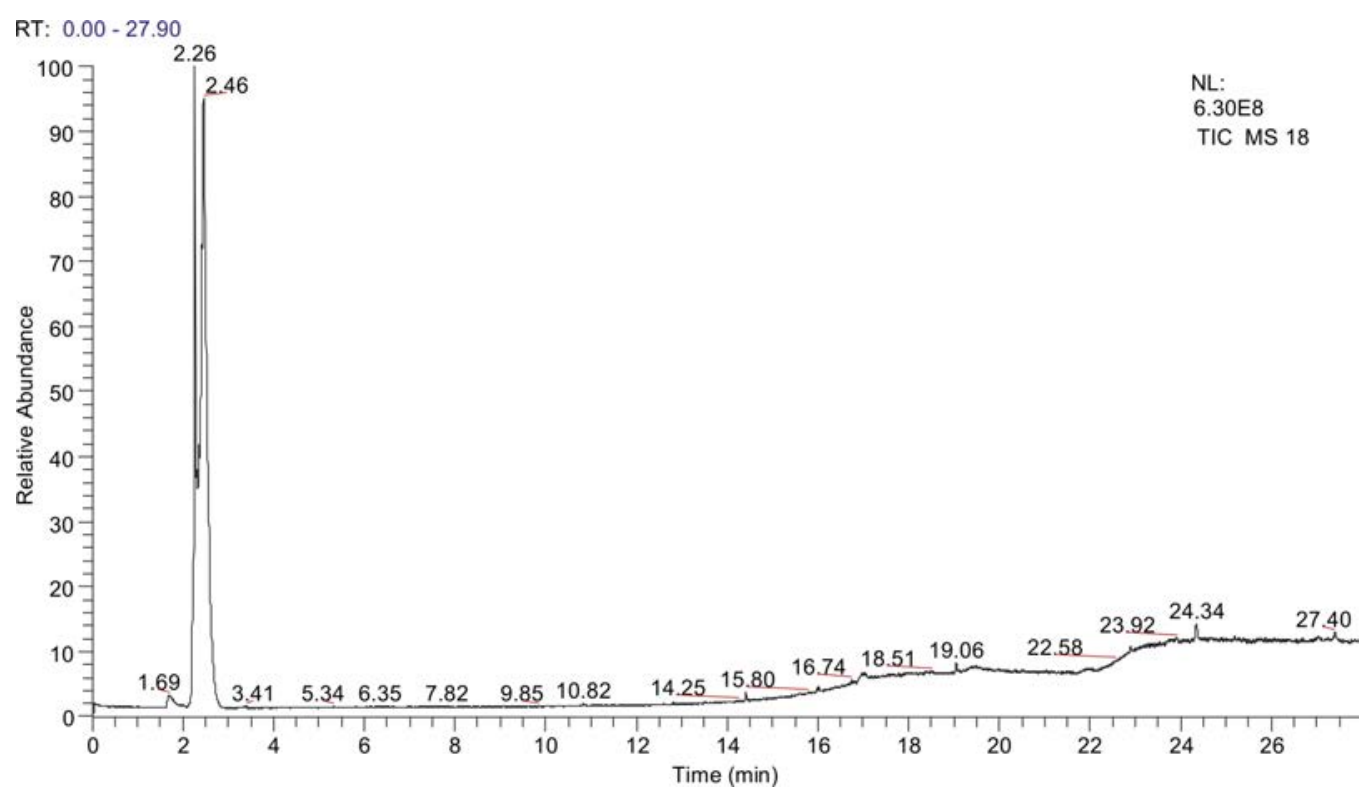

Figure 6. Fatty acids in blood of experimental animals with hypercholesterolemia after 1 month of Biomays intake

We quantitatively analyzed certain fatty acids in animals with hypercholesterolemia that were given Biomays food additive and compared the results with animals that weren't given it (Figure 7). The analysis revealed that contents of such saturated and monounsaturated fatty acids as palmitic, palmitic-oleic, stearic, and oleic acid went down by $46.0 \%, 64.0 \%$, $37.7 \%$, and $20.0 \%$ accordingly in animals that received Biomays against animals that didn't. At the same time concentrations of such polyunsaturated fatty acids as linoleic and linolenic on the contrary increased by $29 \%$ and $141 \%$ accordingly. Hence, treating animals with hyperlipidemia with Biomays food additive promoted a considerable decrease in concentrations of saturated fatty acids in blood and an increase in polyunsaturated ones such as linoleic and linolenic acid. Bearing in mind that these acids belong to Omega- 3 and Omega- 6 fatty acids, it becomes obvious that they play an important role in metabolism in a body as a whole and cholesterol metabolism in particular. Shift which we revealed in fatty acids structure of blood taken form experimental animals with hypercholesterolemia underlie positive shifts in spectra of low and high density lipoproteins against Biomays food additive intake.

We also performed a study on effects produced by Biomays food additive on prac- tically healthy people; the results also revealed quite a similar fatty acids structure in blood.

As we can see from Figure 8, quantitative analysis of certain fatty acids in blood of practically healthy people who were given Biomays food additive revealed that palmitic acid contents decreased by almost 2 times after 2 months of Biomays intake. At the same time, contents of polyunsaturated fatty acids, such as linoleic and linolenic acid, increased by 3.5 and 2.6 times accordingly. Arachidonic acid concentration also grew (Figure 8), but this growth was less apparent.

Therefore, our research revealed that the examined food additive, when given to practically healthy people, promoted an increase in polyunsaturated fatty acids in blood, in particular linoleic, linolenic, and arachidonic acid; it again confirms that Biomays produces positive effects on lipid metabolism.

Therefore, our research results indicate that both hypolipidemic medication ultrox and Biomays food additive made of wheat germ produced obvious positive effects on high and low density lipoproteins spectra in animals with hypercholesterolemia; their combined intake promoted more apparent hypolipidemic effects. 


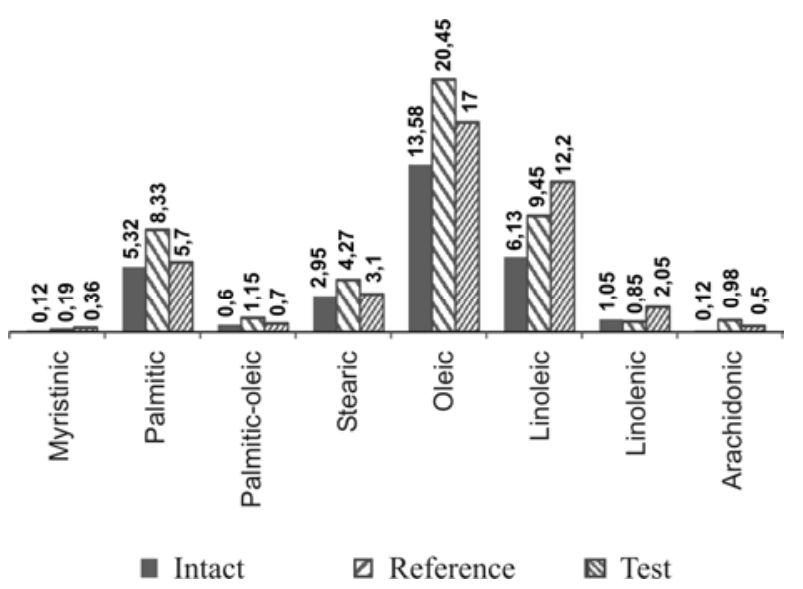

Figure 7. Comparative contents of certain fatty acids in blood of experimental animals with hypercholesterolemia after 1 month of Biomays intake

Conclusion. Experimentally induced hyperlipidemia resulted in higher concentrations of atherogenic very low density and low density lipoproteins (VLDLP and LDLP) and a decrease in concentration of anti-atherogenic high density lipoproteins in blood plasma of rabbits form the test group against intact animals. Mono-therapy with ultrox in a dose equal to $0.5 \mathrm{mg} / \mathrm{kg}$ and Biomays statistically significantly reduced TCS and LDLP contents in comparison with animals that were not given any treatment. When both preparations were taken together,

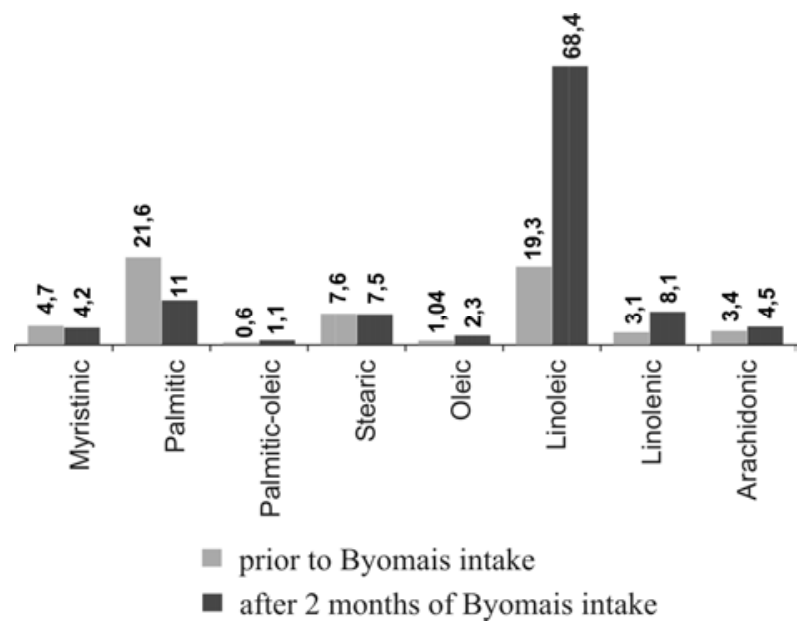

Figure 8. Comparative contents of certain fatty acids in blood of practically healthy people after 2 month of Biomays intake

there was an authentic decrease in LDLP and VLDLP contents.

Basing on the accomplished research, we developed theoretical grounds for recommending treatment with Biomays food additive to patients receiving anti-hyperlipidemia therapy who had troubles with statins. Application of this biologically active additive helps reducing statins doses.

Funding. The research was not granted any sponsor support.

Conflict of interests. The authors declare there is no any conflict of interests.

\section{References}

1. Oganov R.G. Profilaktika serdechno-sosudistykh zabolevanii vracha obshchei praktiki [Prevention of cardiovascular diseases by a general practitioner]. Kardiologiya Uzbekistana, 2006, no. 1, pp. 17-20 (in Russian).

2. Graham I., Atar D., Borch-Johnsen K., Boysen G., Burell G., Cifkova R., Dallongeville J., De Backer G. [et al.]. European Guidelines on Cardiovascular Disease Prevention in Clinical Practice: Executive Summary: Fourth Joint Task Force of the European Society of Cardiology and Other Societies on Cardiovascular Disease Prevention in Clinical Practice (Constituted by Representatives of Nine Societies and by Invited Experts). Eur. Heart. J., 2007, vol. 28, no. 19, pp. 2375-2414. DOI: 10.1093/eurheartj/ehm316

3. Grundy S.M., Cleeman J.I., Merz C.N., Brewer Jr. H.B., Clark L.T., Hunninghake D.B., Pasternak R.C., Smith Jr. S.C. [et al.]. Implications of Recent Clinical Trials for the National Cholesterol Education Program Adult Treatment Panel III Guidelines. Circulation, 2004, vol. 110, no. 2, pp. 227-239. DOI: 10.1161/01.CIR.0000133317.49796.0E

4. Innis S.M., Green T.J., Halsey T.K. Variability in the trans fatty acid content of foods within a food category: implications for estimation of dietary trans fatty acid intakes. J. Am. Coll. Nutr., 1999, no. 18, pp. 255-260. DOI: 10.1080/07315724.1999.10718860 
5. Kavanagh K., Jones K.L., Sawyer J., Kelley K., Carr J.J., Wagner J.D., Rudel L.L. Trans fat diet induces abdominal obesity and changes in insulin sensitivity in monkeys. Obesity (Silver Spring), 2007, vol. 15 , no. 7 , pp. 1675-1684. DOI: 10.1038/oby.2007.200

6. Titov V.N. Phylogenetically theory of general pathology, nutritive disturbance is the basis of metabolic syndrome pathogenesis, overeating syndrome. Leptin and adiponectin role. Eur. J. Med., 2013, vol. 1, no. 1, pp. 48-60. DOI: 10.13187/ejm.2013.1.48

7. Expert Panel on Detection, Evaluation, and Treatment of High Blood Cholesterol in Adults. Executive Summary of the Third Report of the National Cholesterol Education Program (NCEP) Expert Panel on Detection, Evaluation, And Treatment of High Blood Cholesterol In Adults (Adult Treatment Panel III). JAMA, 2001, vol. 285, no. 19, pp. 2486-2497. DOI: 10.1001/jama.285.19.2486

8. Van Tol A., Zock P.L., Van Gent T., Scheek L.M., Katan M.B. Dietary trans fatty acids increase serum cholesterylester transfer protein activity in man. Atherosclerosis, 1995, vol. 115, no. 1, pp. 129-134. DOI: 10.1016/0021-9150(94)05509-h

9. Zarodysh pshenitsy [Wheat germ]. MIRAGRO. Available at: http://miragro.com/zarodyshzhizni-vitazar.html (02.09.2014) (in Russian).

10. Erkkilä A.T., Lichtenstein A.H., Mozaffarian D., Herrington D.M. Fish intake is associated with a reduced progression of coronary artery atherosclerosis in postmenopausal women with coronary artery disease. Am. J. Clin. Nutr., 2004, vol. 80, no. 3, pp. 626-632. DOI: 10.1093/ajcn/80.3.626

11. Titov V.N., Lisitsyn D.M. Plasma content of cholesterol and glycerol alcohols depends on the number of fatty acid double bonds in lipoprotein lipid pool. Bull. Exp. Biol. Med., 2006, vol. 142, no. 5, pp. 577-580. DOI: 10.1007/s10517-006-0422-7

12. Guseva D.A., Prozorovskaya N.N., Shironin A.V. Antioksidantnaya aktivnost' rastitel'nykh masel s raznym sootnosheniem omega-6 i omega-3 zhirnykh kislot [Antioxidant activity of vegetable oils with different proportions of omega- 6 and omega-3 fatty acids]. Biomeditsinskaya khimiya, 2010, no. 3, pp. 342-350 (in Russian).

13. Kurbanov R.D. Perspektivy razvitiya kardiologii v Uzbekistane [Cardiology in Uzbekistan: prospects of development]. Meditsinskii zhurnal Uzbekistana, 2002, vol. 3, no. 2, pp. 10-12 (in Russian).

14. Makarov V.I., Belyakov N.A. Produkty pitaniya funktsional'nogo naznacheniya. Metody lecheniya [Functional food products. Treatment procedures]. Arkhangel'sk, Severo-Zapadnoe izdatel'stvo Publ., 2013, 462 p. (in Russian).

15. Issledovanie effektivnosti masla zarodyshei pshenitsy [Research on efficiency of wheat germ oil]. Moscow, GU Gorodskaya poliklinika № 230 Publ., 2004, 2 p. (in Russian).

16. Dashti N., Feng Q., Freeman M.R., Gandhi M., Franklin F.A. Trans polyunsaturated fatty acids have more adverse effects than saturated fatty acids on the concentration and composition of lipoproteins secreted by human hepatoma HepG2 cells. J. Nutr., 2002, vol. 132, no. 9, pp. 2651-2659. DOI: $10.1093 / \mathrm{jn} / 132.9 .2651$

17. Mariscalco G., Sarzi Braga S., Banach M., Borsani P., Bruno V.D., Napoleone M., Vitale C., Piffaretti G. [et al.]. Preoperative n-3 polyunsatured fatty acids are associated with a decrease in the incidence of early atrial fibrillation following cardiac surgery. Angiology, 2010, vol. 61, no. 7, pp. 643-650. DOI: 10.1177/0003319710370962

18. Chazov E.I. Problemypervichnoiivtorichnoiprofilaktikiserdechno-sosudistykhzabolevanii v Rossiii SNG [Issues related to primary and secondary prevention of cardiovascular diseases in Russia and CIS countries]. Kardiologiya Uzbekistana, 2006, no. 1, pp. 15-17 (in Russian).

19. Arruzazabala M., Carbajal D., Molina V. Effect of policosanol on cerebral ischemia in Mongolian gerbils: Role of prostacyclin and thromboxane Az. Prostaglandins. Leuko. Essent. Fatty Acids, 2012, vol. 49, no. 3, pp. 695-697. DOI: 10.1016/0952-3278(93)90080-g

20. Arruzazabala M., Valdes S., Mas R. Effect of policosanol successive dose increase in platelet aggregation healthy volunteers. Pharmacol. Res., 2013, vol. 34, no. 5-6, pp. 181-185. DOI: 10.1006/phrs.1996.0086

21. Ragino Yu.I., Vavilin V.A., Salakhutdinov N.F., Makarova S.I., Stakhneva E.M., Safronova O.G. Izuchenie antiaterogennykh effektov simvagli na modeli giperkholesterinemii u krolikov [Studies on antiatherogenic effects produced by simvagli on model hypercholesterolemia in rabbits]. Ateroskleroz, vol. 6, no. 1, pp. 5-11 (in Russian). 
22. Lee H.Y., Woo J., Chen Z.Y., Leung S.F., Peng X.H. Serum fatty acid, lipid profile and dietary intake of Hong Kong Chinese omnivores and vegetarians. Eur. J. Clin. Nutr., 2000, vol. 54, no. 10, pp. 768-773. DOI: 10.1038/sj.ejen.1601089

23. Ariel A., Serhan C. Resolvins and protectins in the termination program of acute inflammation. Trends Immunol, 2011, vol. 28, no. 4, pp. 176-183.

24. Arruzazabala M., Carbajal D., Mas R. Comparative study of policosanol, aspirin and the combination therapy policosanol-aspirin on platelet aggregation in healthy volunteers. Pharmacol. Res, 2010, vol. 36, no. 4, pp. 293-297. DOI: 10.1006/phrs.1997.0201

25. Anichkov N.N., S.S. Khalatov. Novye dannye po voprosu o patologii i etiologii ateroskleroza [New data on atherosclerosis pathology and etiology]. Russkii vrach, 1913, no. 8, pp. 184-186 (in Russian).

26. Azizova D.M., Sabirova R.A., Kulmanova M.U. Effects of biomaise on aterogenic plasma index during the development of experimental hyperholesterynemia. Meditsinskie novosti, 2019, no. 7, pp. 78-80 (in Russian).

27. Lankin V.Z., Tikhaze A.K., Kukharchuk V.V. Antioksidanty v profilaktike i kompleksnoi terapii ateroskleroza [Antioxidants in preventing and complex treatment of atherosclerosis]. Fundamental'nye issledovaniya i progress kardiologii: sbornik trudov nauchnoi sessii. Moscow, Mash-mir Publ., 2002, pp. 141-146 (in Russian).

28. Brochot A., Guinot M., Auchere D. Effects of alpha-linolenic acid vs. docosahexaenoic acid supply on the distribution of fatty acids among the rat cardiac subcellular membranes after a short- or long-term dietary exposure. Nutr. Metab. (Lond), 2013, vol. 10, no. 3, pp. 115-119. DOI: 10.1186/1743-7075-6-14

29. Lefevre M., Champagne C.M., Tulley R.T., Rood J.C., Most M.M. Individual variability in cardiovascular disease risk factor responses to low-fat and low-saturated-fat diets in men: body mass index, adiposity, and insulin resistance predict changes in LDL cholesterol. Am. J. Clin. Nutr., 2005, vol. 82, no. 5, pp. 957-963. DOI: 10.1093/ajen/82.5.957

30. Hippisley-Cox J., Coupland C. Unintended effects of statins in men and women in England and Wales: population based cohort study using the Q Research database. BMJ, 2010, vol. 340, pp. 2197. DOI: $10.1136 /$ bmj.c2197

31. Mozaffarian D., Cao H., King I.B., Lemaitre R.N., Song X., Siscovick D.S., Hotamisligil G.S. Trans-palmitoleic acid, metabolic risk factors, and new-onset diabetes in U.S. adults: a cohort study. Ann. Intern. Med., 2010, vol. 153, no. 12, pp. 790-799. DOI: 10.7326/0003-4819-153-12-201012210-00005

32. Kon' I.Ya. Ispol'zovanie polinenasyshchennykh zhirnykh kislot $\mathrm{v}$ pitanii zdorovykh detei [Use of poly-unsaturated fatty acids in food provided for healthy children]. Lechashchii vrach, 2011, no. 1, pp. 42-47 (in Russian).

33. Gapparov M.G. Funktsional'nye produkty pitaniya [Functional food products]. Pishchevaya promyshlennost', 2013, no. 3, pp. 11-12 (in Russian).

34. Titov V.N., Amelyushkina V.A., Rozhkova T.A. The conformation of apob-100 in phylogenetically and functionally different lipoproteins of low and very low density: algorithm of formation of phenotypes of hyper lipoproteinimia (a lecture). Klinicheskaya laboratornaya diagnostika, 2014, no. 1, pp. 27-38 (in Russian).

35. Mazidi M., Gao H.K., Vatanparast H., Kengne A.P. Impact of the dietary fatty acid intake on C-reactive protein levels in US adults. Medicine (Baltimore), 2017, vol. 96, no. 7, pp. e5736. DOI: 10.1097/MD.0000000000005736

36. Mozaffarian D., De Oliveira Otto M.C., Lemaitre R.N., Fretts A.M., Hotamisligil G., Tsai M.Y., Siscovick D.S., Nettleton J.A. Trans-Palmitoleic acid, other dairy fat biomarkers, and incident diabetes: the Multi-Ethnic Study of Atherosclerosis (MESA). Am. J. Clin. Nutr., 2013, vol. 97, no. 4, pp. 854-861. DOI: $10.3945 /$ ajen.112.045468

37. Mazidi M., Michos E.D., Banach M. The association of telomere length and serum 25-hydroxyvitamin D levels in US adults: the National Health and Nutrition Examination Survey. Arch. Med. Sci., 2017, vol. 13, no. 1, pp. 61-65. DOI: 10.5114/aoms.2017.64714

38. Mensink R.P., Zock P.L., Kester A.D., Katan M.B. Effects of dietary fatty acids and carbohydrates on the ratio of serum total to HDL cholesterol and on serum lipids and apolipoproteins: a meta-analysis of 60 controlled trials. Am. J. Clin. Nutr., 2003, vol. 77, no. 5, pp. 1146-1155. DOI: 10.1093/ajen/77.5.1146 
39. Klein-Platat C., Drai J., Oujaa M., Schlienger J.L., Simon C. Plasma fatty acid composition is associated with the metabolic syndrome and low-grade inflammation in overweight adolescents. Am. J. Clin. Nutr., 2005, vol. 82, no. 6, pp. 1178-1184. DOI: 10.1093/ajen/82.6.1178

40. Arruzazabala M., Carbajal D., Molina V. Effect of policosanol on cerebral ischemia in mongolian gerbils: Role of prostacyclin and thromboxane Az. Prostaglandins Leukot \& Essent. Fatty Acids, 2012, vol. 49, pp. 695-697.

41. Micha R., Mozaffarian D. Trans fatty acids: effects on metabolic syndrome, heart disease and diabetes. Nat. Rev. Endocrinol., 2009, vol. 5, no. 6, pp. 335-344. DOI: 10.1038/nrendo.2009.79

42. Vega-Lopez S., Ausman L.M., Jalbert S.M., Erkkila A.T., Lichtenstein A.H. Palm and partially hydrogenated soybean oils adversely alter lipoprotein profiles compared with soybean and canola oils in moderately hyperlipidemic subjects. Am J. Clin. Nutr., 2006, vol. 84, no. 1, pp. 54-62. DOI: $10.1093 /$ ajen/84.1.54

43. Von Schacky C., Angerer P., Kothny W., Mudra H. The effect of dietary omega-3 fatty acids on coronary atherosclerosis. A randomized, double-blind, placebo-controlled trial. Ann. Intern. Med., 1999, vol. 130, no. 7, pp. 554-622. DOI: 10.7326/0003-4819-130-7-199904060-00003

44. Chajes V., Thiebaut A.C., Rotival M., Gauthier E., Maillard V., Boutron-Ruault M.-C., Joulin V., Lenoir G.M., Clavel-Chapelon F. Association between serum trans-monounsaturated fatty acids and breast cancer risk in the E3N-EPIC Study. Am. J. Epidemiol., 2008, vol. 167, pp. 1312-1320. DOI: $10.1093 / \mathrm{aje} / \mathrm{kwn} 069$

45. Imamura F., Micha R., Wu J.H., De Oliveira Otto M.C., Otite F.O., Abioye A.I., Mozaffarian D. Effects of saturated fat, polyunsaturated fat, monounsaturated fat, and carbohydrate on glucose-insulin homeostasis: a systematic review and metaanalysis of Randomised Controlled Feeding Trials. PLoS Med, 2016, vol. 13, no. 7, pp. e1002087. DOI: 10.1371/journal.pmed.1002087

46. Mazidi M., Kengne A.P., Banach M. Mineral and vitamins consumption is associated with longer telomeres among US adults. Pol. Arch. Med. Wewn., 2017, vol. 127, no. 2, pp. 87-90. DOI: 10.20452/pamw.3927

Azizova D.M., Mavlyanov I.R., Sabirova R.A., Kulmanova M.U., Soliev A.B., Zharylkasynova G.Zh. Developing new approaches to hyperlipidemia correction taking into account changes in fatty acids structure of blood serum. Health Risk Analysis, 2020, no. 2, pp. 152-163. DOI: 10.21668/health.risk/2020.2.17.eng

Received: 24.03.2020

Accepted: 13.06.2020

Published: 30.06.2020 